\title{
柔軟性の階級的因子構造
}

一大学男子水泳選手一

$\begin{array}{llll}\text { 出 } & \text { 村 } & \text { 慎 } & \text { 一 (筑波大学) } \\ \text { 松 } & \text { 浦 } & \text { 義 } & \text { 行 (筑波大学) } \\ \text { 田 } & \text { 中 } & \text { 喜 代 次 (筑波大学) } \\ \text { 田井村 } & \text { 明 } & \text { 博 (筑波大学) } \\ \text { 服 } & \text { 部 } & & \text { 隆 (筑波大学) } \\ \text { ムハマッド・アンワル・ } & \text { パサウ (筑波大学) }\end{array}$

（昭和54年 7月16日 受付）

\section{Hierarchical Factorial Structure of Flexibility in College Male Swimmers}

\author{
Shinichi Demura* \\ Yoshiyuki Matsuura* \\ Kiyoji Tanaka* \\ Akihiro Taimura* \\ Takashi Hattori* \\ Pasau M. Anwar*
}

\begin{abstract}
The purpose of this study was to examine a structure of flexibility in swimmers from the viewpoint of the factor analysis. Twenty-four test items which were based upon the hypothesis given by Nicks and Fleishman were selected and administered to the 153 college male swimmers. ROTOHIST technique developed by Zavara was applied to an unrotated factor pattern matrix produced by the principal factor solution, and then, the hierarchical factorial structure of flexibility was investigated.

As a result, 12 factors were extracted, which did explain more than 85 per cent of the total variance; and according to the aforementioned technique, two factors with the highest eigenvalues were rotated at first and interpreted. And then, each of the rest of the factors corresponding to the next highest eigenvalue was added in due order to the previously rotated factors and again interpreted. This procedure was thus repeated in the same manner until after the eleventh rotation. While the rotated factors were interpreted at each rotation level, they were synthesized and arranged also at the whole level. Eventually, the authors drew a tree diagram. The tree diagram shows that a general flexibility exists and it may part such two ability areas as static flexi-
\end{abstract}

* University of Tsukuba, Institute of Health and Sports Sciences, Niihari-gun, Ibaraki, (305) 
bility and dynamic flexibility (i.e., swimming speed), just as Nicks and Fleishman hypothesized in their paper; however, the investigated structure of flexibility was somewhat different from theirs. That is, it was inferred that flexibiliy area of motor ability does not simply consist of some subdivided flexibility areas that were pointed out by Nicks and Fleishman, but of more complex domains that were subdivided and/or partly integrated as the degree of complexity of factors decreases.

(Shinichi Demura, Yoshiyuki Matsuura, Kiyoji Tanaka, Akihiro Taimura, Takashi Hattori, Pasau M. Anwar: Hierarchical Factorial Structure of Flexibility in College Male Swimmers. Jap. J. Phys. Educ., Vol. 24, No. 3, Dec., pp. 217 226).

\section{I . 腥}

D.C. Nicks と E.A. Fleishman ${ }^{27)}$ は，1962年 にそれまでに発表された因子分析的研究を総合 ・整理し，柔軟性の能力領域に図1に示すような 階級的因子構造を仮定するのが妥当としている。

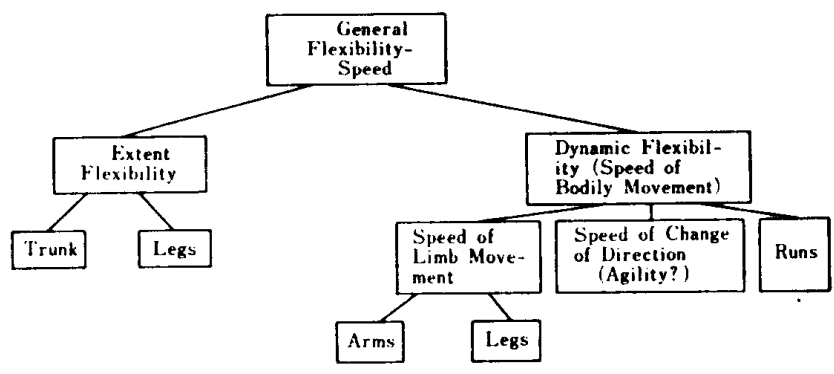

図 1 柔軟性一スピード能力領域の 階級的因子構造

このよ5に, 知能, 体力, 運動能力, 筋力とい った諸能力に階級的構造を仮定することの妥当性 は，松浦 22)23)24)25)，C. Burt をはじめ L.A. Larson と R.D. Yocom ${ }^{19)}$, H.H. Clarkes), 井上ら ${ }^{16)}$ ${ }^{17)}$ ，松田 ${ }^{26)}$ 等によって主張されているが，この立 場，すなわち，階級的因子モデルを探用し，能力 の構造を検討しょ5とした研究は限られており，

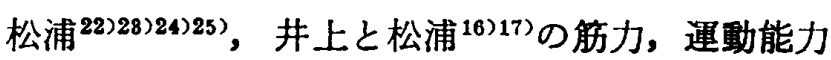
に関する報告があるのみである。

柔㳄性は各種運動の成就に程度の差こそあれ貢 献しているものと考えられるが，水泳運動におけ る柔犁性の必要性かつ重要性は， J.E. Counsil$\operatorname{man}^{738) 9)}$, T.K. Cureton ${ }^{10) 1112)}$ をはじめ多くの二 一チ・研究者たち(14)18)20121)によって主張されてい る.また, G.L. Bester ${ }^{1)}$ をはじめ多くの人たち 13)14)15)18）に上って，柔粎性の向上が水泳成績の们 上をもたらしたという報告がなされている。
そこで，本研究では，階級的因子モデルの立場 に立ち，水泳選手を対象として得られた資料を手 がかりとして柔軟能力の因子構造を検討すること にした。

$$
\text { II. 方法 }
$$

\section{1 . 標本}

関東 8 大学の水涾チームから選ばれた 153 名の 男子水泳選手で，いずれも 3 年以上の競技経験が あった。平均年齢，身長，体重は各々 20.1 歳, $171.4 \mathrm{~cm}, 65.8 \mathrm{~kg}$ であった。

\section{2. テスト変数}

テスト項目は, D.C. Nicks と E.A. Fleishm$\mathrm{an}^{27)}$ の仮説を作業仮説とし，妥当性，信頼性，実 用性を考虑して選択した。

(1) 静的柔㳄性

(1)体前屈, (2)体後届, (3)体右側届, (4)体左側 届, (5)体右捻転, (6)体左捻転，(7)肩前挙上，(8)肩 後举上, (9府側方挙上, (10)足首伸展, (11)足首屈 曲, 12股外転.

以上のテスト項目の内, (1)と(2), (3)と(4), (5)と (6)（7)と(8)の和から，そして(19)と(11)の差からそれ ぞれ，(13体前後可動性，(14体側届可動性，(15)体捻 転可動性, (16)肩の前後挙可動性, (17)足首伸届可動 性が求められた。

（2）動的柔軟性（スピード・敏揵性）

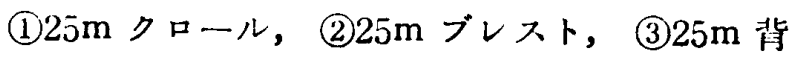
涾, (4) $25 \mathrm{~m}$ バタフライ, (5) $25 \mathrm{~m}$ クロールプル, (6) $25 \mathrm{~m}$ ロールキック, (7)25mクロールプル数, (8)

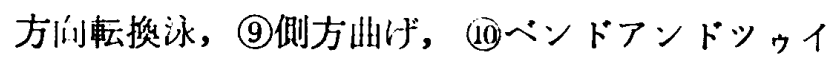
ストとタッチ，(11)タッピング，(12)ステッピング, (13)バーピーテスト. 
衰 1 平均值・權管偏差・信頼性

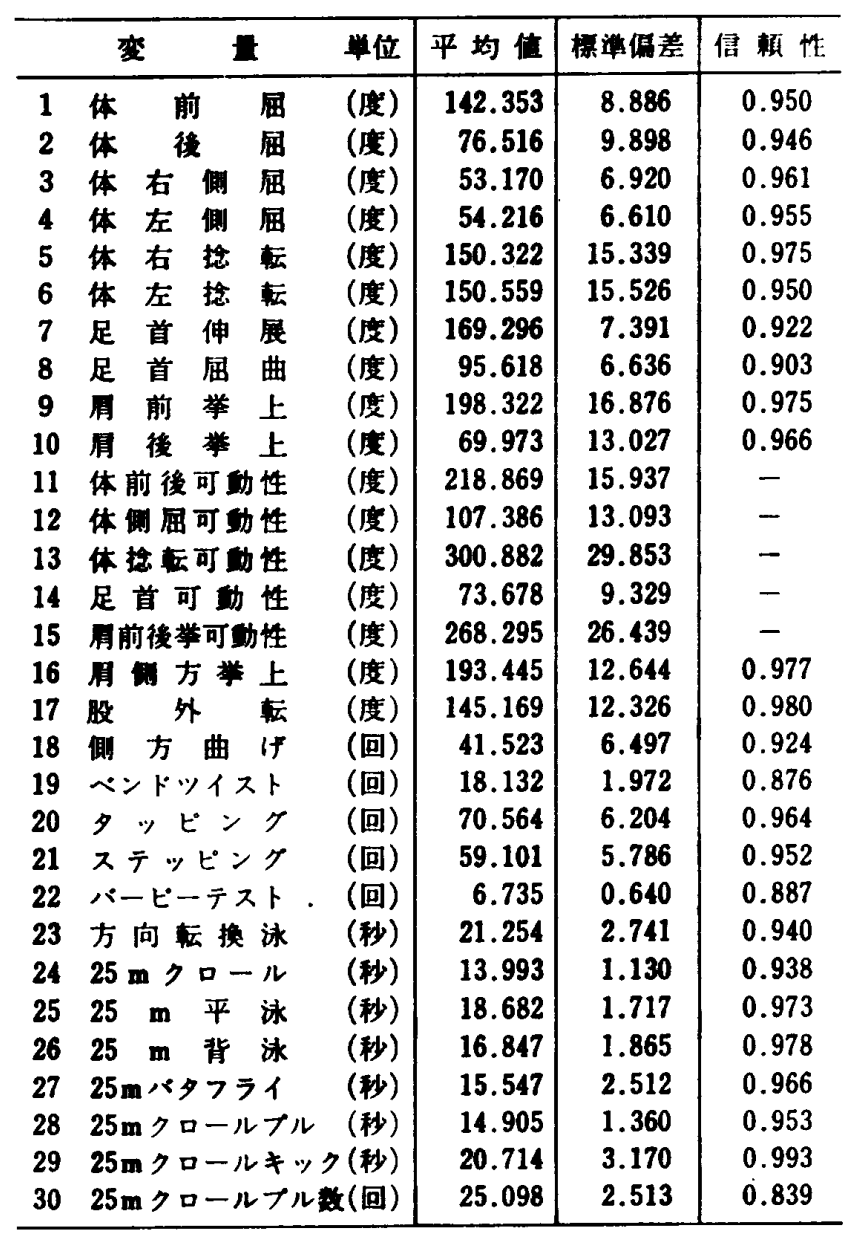

静的柔杴性は，すべて妥当性，信頼性が高いと 報告されている角度法淿) を用いて测定がなされ た. 方向転换泳は，水中に一定の間隔に浮かべら れた三つのボールのまわりを規定のコースに従っ てできるだけ速く移動する際のタイムを测定し

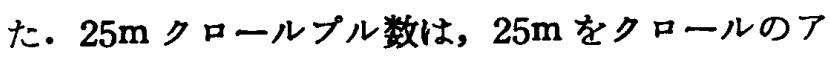
一ムプルのみで全力で泳いだ際に要したプル数を 湘定值とした.

他のテストは一般的に行なわれているテスト方 法に従って行なわれた。

以上のテスト変数の平均值, 標萍偏差, 信頼性 は表 1 に示してある。

\section{(3) 分析法}

柔饮能力の階䄲的因子構造を見い出すために， A. Zavala ${ }^{29)}$ 考案したROTOHIST 法を因子解 法技術として用いることにした。それは以下の手 順に従って行なわれた。

表 2 はテスト 変量間の相関行列を作成したもの であるが，まずこれに主因子解法を適用し，湘定
值には誤差が含まれていることを見込んで，全分 散の $85 \%$ 以上が説明される因子を抽出した。その 結果, 表 3 に示されているよ5な因子が抽出され た. 次に，柔軟能力の系統樹を描くために，次の ような方法で因子の回転が行なわれた。

(1)最大の固有值（最大の 分散量）に対応する因子 を考察する（表 3 の第 1 因子).

(2)次に，第 2 番目に大きな固有值に対応する因子 （表 3 の第 1 因子）を加えて，2 個の因子を Normal Varimax 法にて值交回転を行い，抽出 された 2 因子を考察する。

(3)次に, 上記の 2 個の因子に, 表 3 の 3 番目に大 きな固有值に対応する因子を加えて，3 個の因 子を(2)と同じ方法にて回転し，抽出された 3 因 子を考察する.

以下，順次表 3 の固有值の大きいものから一つ ずつ因子を加えて回転し，各间の回転が完了する ごとに因子を解釈していく.

因子数を順次增加させるとい5ことは，全分散 の説明される量が増大寸ることを意味するが，本 研究では全分散の約 85\%が説明される12因子を抽 出し，11回の回転を行い，得られた結果から柔軟 能力の階級的構造を検討することにした。

\section{III. 结果亡考察}

表 3 と 4 は，前節の分析法のところで述べた A. Zavala の ROTOHIST 法を表 2 で示した相 関行列に適用して得られた結果である，以下，各 回転レベル毎に抽出された因子を解釈していく。

(1) 回転レペル 1 ;

表 3 の最大の固有值（8.15）に対応する第 1 因 子を考察すると，この因子の貢献度は $27.2 \% て ゙ ，$ 因子負荷量はタッピング，ステッピング，バーピ 一テスト以外のすべての変量と有意な相関を示し ている.したがって，この因子はこれらの変量の 運動成就に程度の差こそあれ共通に関与する能力 領域と考えることがでさる・かかる理由から，こ の因子は基礎的あるいは一般的柔軟因子と解釈す ることができるであろう・

(2) 回転レベル 2 ;

(1)で考察した第 1 因子に表 3 の第 2 番目に大き な固有值に対応寸る因子，すなわち第 2 因子を加 
毒 2 相閣行列

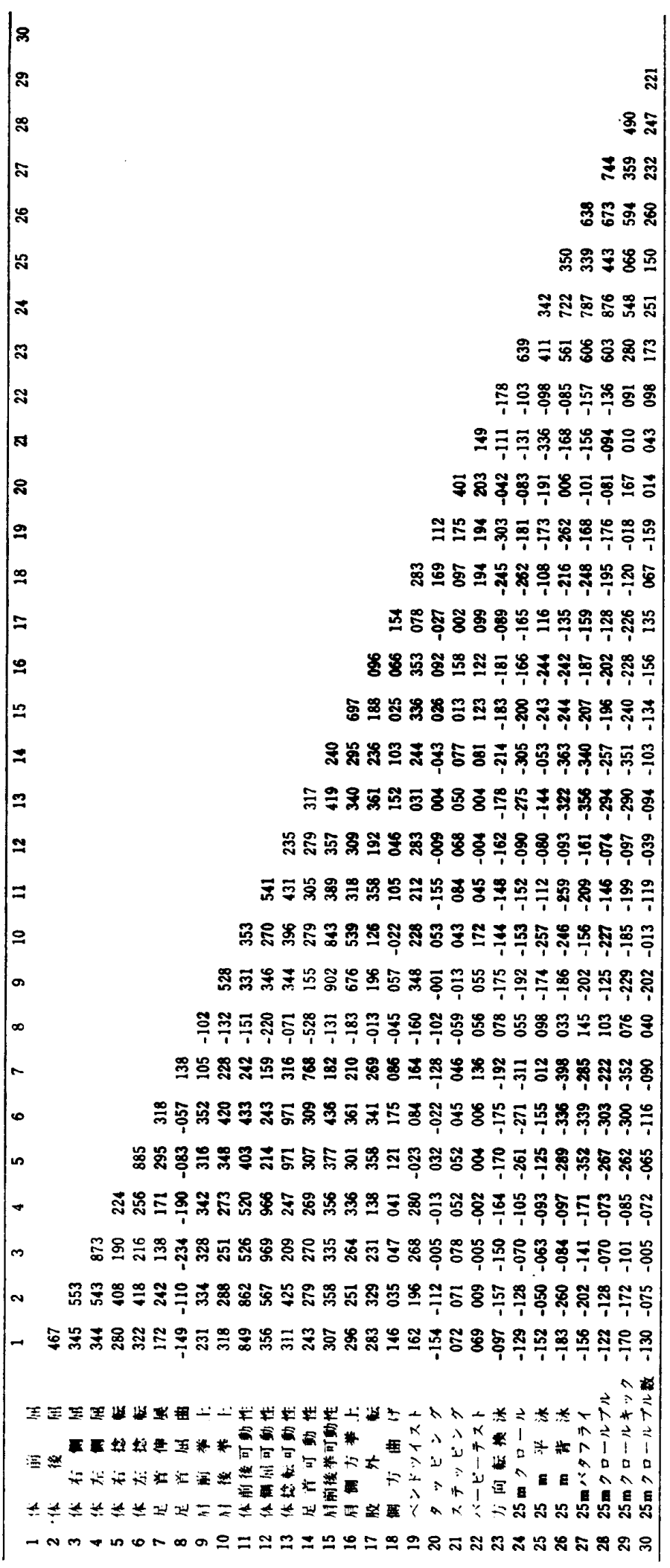

沛：小数点は除いてある

えて，2 湖の因子を Normal Varimax 法にて们 交回伝し，いずれの因子に高い負荷量を示してい

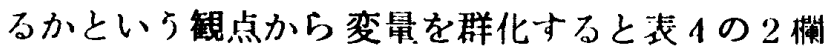

の通りとなる・群化された 2 因子を解釈する と，第 1 因子は体前・後屈，体㑡届，体捻枟， 肩の前举・後挙 ・侧方挙上, 等々の主として 静的柔故性を代表する変量に高い負荷量を示 し，第 2 因子はクロール，背泳，ハタフ イ，方向枟換泳，等々の泳スピードを代表す る変量に高い負荷量を示している．したがっ $\tau$ ，第 1 因子，第 2 因子は各々静的柔吹因 子,泳スピード因子と解粎されるであろ5。ま た, D.C. Nicks と E.A. Fleishman"27) によ れば，柔收性とスピード能力が結合した能力 領域を動的柔吹性の能力領域と仮定している

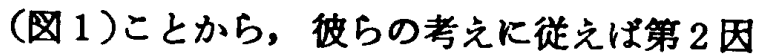
子は動的柔欧因子とす解釈されるであろ5。

(3) 回枟レベル 3 ;

(2)において抽出された 2 因子に，表 3 の第 3 因子を加之，3 個の因子を(2)においてと同 様な方法で回枟し，最大の因子負荷量につい て変量を群化すると表 4 の 3 闌の通りとな る・ここで群化された 3 因子を解釈すると, 第 1 因子は体前・後届, 体側届, 肩の前挙・ 後挙・僋方挙上,等々の変量飞, 第 2 因子はV ベル 2 においてとほぼ同様な变量に，第 3 因 子は体捻枟等々の変量に高い負荷量を示して いる・したがって，各因子は各々体前届・後 届，体僛届，及び肩の柔顿因子，涾スピード 因子，及び体捻転柔欧因子と解釈されるであ ろ5.また，表 4 の 2 と 3 欄からみて，ここ で解釈された体前・後居，体側屈，及び局の 柔㪀因子と体捻枟柔㪀因子は，レペル 2 にお いて静的柔呚性と解釈された能力領域が分化 して形成されたものと推測される。

(4) 回転レベル 4 ;

今までと同棣に，レベル 3 において抽出され た 3 個の因子に，表 3 の第 4 因子を加えて， 同様な方法を用いて州転し，同様な観点から 変鼠を群化すると表 4 の 4 欄の通りとなる. 群化された 4 因子を解釈すると，第 2 因子， 第 3 因子はレベル 3 においてとほぼ同様な変量に 河い負荷鼠を示していることから，レヘル3の場 合と同様に，㞹因丁は条々泳スピード因子，体拉 偣柔軟因子と解积されるですろう。东た，第1因 
3 回枟前の因子負荷量及び頁献量・貢献度

\begin{tabular}{|c|c|c|c|c|c|c|c|c|c|c|c|c|c|c|}
\hline 骎 & 数因子 & 1 & 2 & 3 & 4 & 5 & 6 & 7 & 8 & 9 & 10 & 11 & 12 & 其近中l \\
\hline 1 & 前 & 541 & -295 & 053 & -160 & -046 & -074 & -319 & 552 & 107 & 068 & 012 & 008 & 379 \\
\hline 2 & 体律 & 639 & -100 & 066 & -266 & -067 & -140 & -164 & 147 & -080 & 007 & -026 & 080 & 568 \\
\hline 3 & 体有问用 & 557 & -535 & -344 & -342 & -036 & -100 & 109 & -263 & -052 & 030 & -035 & -005 & 597 \\
\hline 4 & 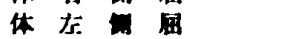 & 580 & -516 & -338 & -295 & 006 & -131 & 121 & -266 & -105 & -042 & 069 & -028 & 603 \\
\hline $\mathbf{5}$ & 体右搭枟 & 648 & -025 & 571 & 150 & -284 & -159 & 208 & -079 & 008 & -067 & 116 & 001 & 421 \\
\hline 6 & 体左 枟 & 696 & -032 & 532 & 177 & -223 & -145 & 141 & -064 & 021 & -132 & 130 & -073 & 485 \\
\hline 7 & 足首 伸晨 & 473 & 140 & 254 & -221 & 093 & 597 & -039 & -054 & -429 & -141 & 095 & -101 & 243 \\
\hline 8 & 足首 间 & -243 & 096 & 237 & 076 & -007 & -209 & -623 & -317 & -500 & -226 & -039 & -095 & 068 \\
\hline 9 & 周 前 业 & 600 & -228 & -116 & 512 & 294 & -010 & -102 & -152 & 129 & -082 & -152 & 063 & 412 \\
\hline 10 & 用 嵝 & 593 & -170 & -020 & 513 & 134 & 115 & -041 & 022 & -099 & 305 & 062 & -054 & 381 \\
\hline 11 & 体前嵝可的诖 & 689 & -407 & 070 & -250 & -066 & -125 & -281 & 402 & 015 & 041 & -010 & 054 & 641 \\
\hline 12 & 体西用可的性 & 588 & -543 & -352 & -330 & -016 & -119 & 119 & -273 & -081 & -005 & 016 & -017 & 640 \\
\hline 13 & 体境枟可助性 & 693 & -029 & 569 & 169 & -260 & -158 & 179 & -073 & 015 & -102 & 126 & -033 & 480 \\
\hline 14 & 足首可蛙 & 562 & 058 & 064 & -240 & 084 & 646 & 370 & 158 & -045 & 025 & 109 & -025 & 320 \\
\hline 15 & 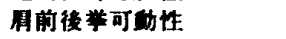 & 681 & -230 & -084 & 584 & 253 & 052 & -086 & -085 & 031 & 104 & -064 & 011 & 517 \\
\hline 16 & 成方方粪上 & 599 & -146 & -168 & 485 & 164 & 136 & 032 & 044 & -015 & -065 & -100 & -059 & 380 \\
\hline 17 & 股办枟 & 392 & -114 & 324 & -162 & -241 & 209 & -250 & -145 & 185 & 115 & -383 & 252 & 167 \\
\hline & 方曲 故 & 239 & 230 & -105 & -065 & -401 & 149 & -250 & -094 & 509 & -303 & -019 & -323 & 110 \\
\hline 19 & ヘンドッイスト & 394 & -012 & -482 & 102 & -003 & 273 & -175 & 008 & 172 & -401 & 093 & -122 & 155 \\
\hline & $\Rightarrow \because ヒ ン ク$ & 013 & 160 & -348 & 296 & -555 & 012 & 260 & -049 & -068 & -141 & -220 & 326 & 026 \\
\hline 21 & ステッビンク & 162 & 142 & -326 & 104 & -515 & 014 & 128 & 292 & -398 & -091 & -366 & -117 & 046 \\
\hline 22 & パーピーテスト & 139 & 135 & -220 & 175 & -365 & 351 & -396 & -069 & -086 & 179 & 352 & 363 & 038 \\
\hline 23 & 方向沅泳 & -494 & -503 & 277 & 128 & -010 & 119 & 116 & 131 & -070 & -080 & -192 & 065 & 497 \\
\hline & $25 \mathrm{~m}>\square-ル$ & -579 & -680 & 089 & 172 & -085 & 104 & 037 & 111 & -032 & -074 & 091 & -086 & 797 \\
\hline 25 & 25 m 泙 泳 & -348 & -330 & 353 & -233 & 127 & 315 & -066 & -256 & 167 & -161 & -140 & -288 & 230 \\
\hline 26 & $25 \mathrm{~m}$ 背 胁 & -614 & -561 & 019 & 137 & -129 & 010 & 084 & -046 & 103 & 022 & 102 & 096 & 682 \\
\hline 27 & $25 \mathrm{~m}$ バタフライ & -604 & -560 & 086 & 160 & 050 & 116 & -049 & 090 & -048 & -082 & -089 & -147 & 678 \\
\hline 28 & $25 \mathrm{~m}$ クロールナ゙ & -562 & -661 & 097 & 104 & -063 & 169 & -001 & 061 & -039 & -191 & -011 & -076 & 752 \\
\hline 29 & 25-クロールキック & -490 & -347 & -213 & 169 & -359 & -064 & -019 & 031 & -025 & -022 & 429 & -053 & 361 \\
\hline 30 & $25 \mathrm{~m}$ クロールナル数 & -235 & -197 & 071 & -004 & -430 & 227 & -099 & -262 & 061 & 569 & -127 & -392 & 094 \\
\hline 故 & $m=$ & 8.15 & 3.63 & 2.38 & 2.12 & 1.71 & 1.49 & 1.33 & 1.18 & 1.05 & 0.96 & 0.86 & 0.77 & 25.63 \\
\hline 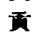 & $(\%)$ & 27.2 & 12.1 & 7.9 & 7.1 & 5.7 & 4.9 & 4.4 & 4.0 & 3.5 & 3.2 & 2.8 & 2.6 & 85.4 \\
\hline
\end{tabular}

注：小数点は除いてある

衰 4 最大因子負荷量によって定義される因子

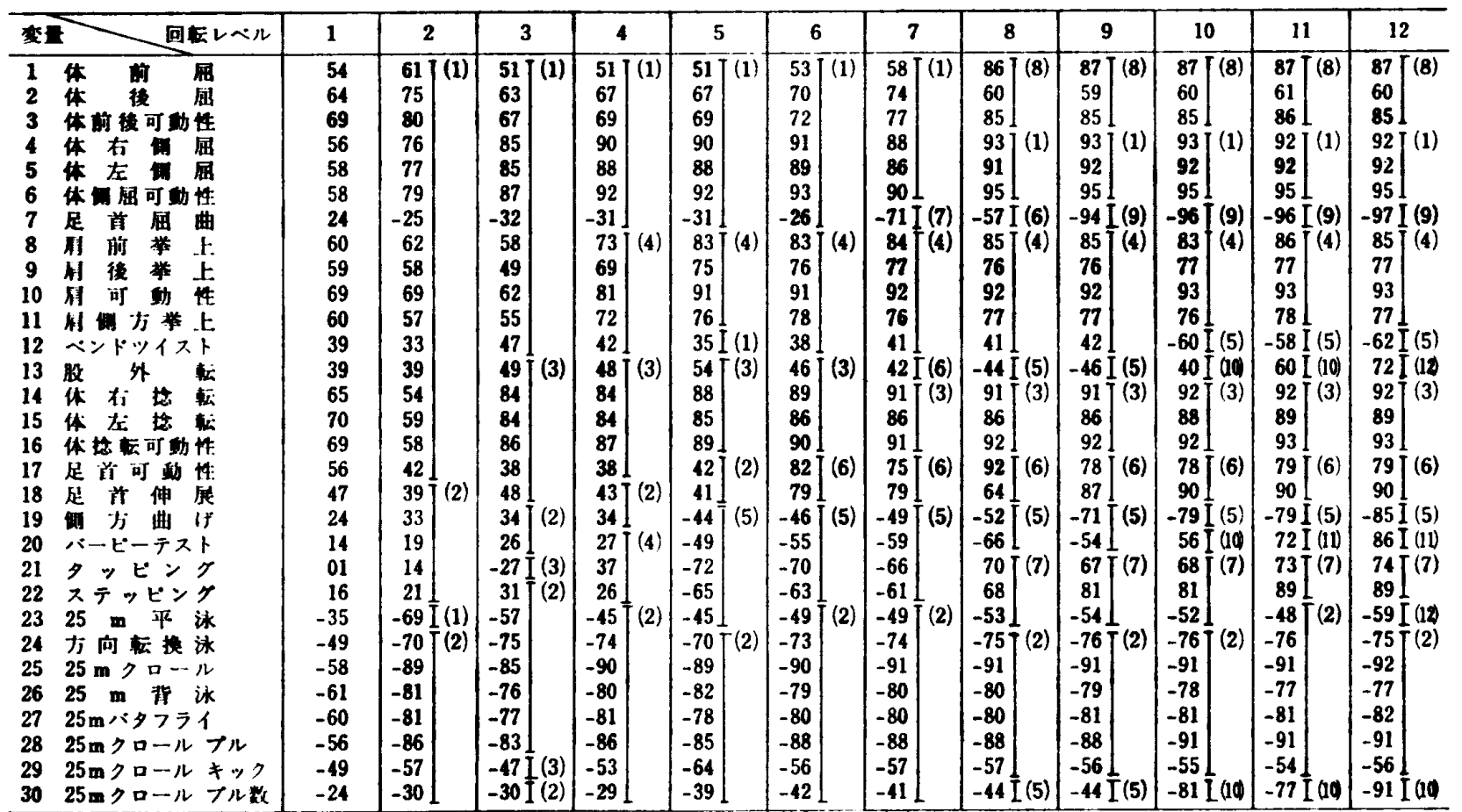

渄1（）内の界号は以了の番㤐を示す 诽2 小数点は除いてある 
子は体前届・後届及び体側届等の変量に, 第 4 因 子は肩の前挙・後挙・側方挙上, 等々の変量に高 い負荷量を示していることから，両因子は各々の 体前・後屈及び体側届柔㳄因子，肩の柔㳄因子之 解釈されるであろう．さらにまた，表 4 の 3 と 4 欄から，上記の两因子は，レベル3において体前 - 後届, 体側届, 及び肩の柔㪀性因子と解釈され た能力領域が分化して形成された 能力領域である と推測される。

(5)＼cjkstart回転レベル 5 ;

これまでと同様な手㮌によって群化された表 4 の 5 縤の 5 因子を解釈すると，第 5 因子以外の因 子は，レベル 4 においてとほぼ同様な変量に高い 真荷量を示していることから，第 1 ，第 2 ，第 3 及び第 4 因子は，レベル 4 の場合と同様に各々体 前・後屈及び体側届柔杴因子，涾スピード因子，

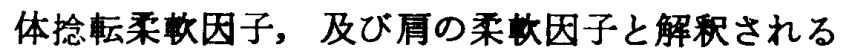
であろう、第 5 因子はタッピングステッピン グ，ハーーピーテスト，側方曲げ，平泳等の四肢及 び身体全体の運動スピードあるいは敏捷性を代表 する変量に高い負荷量を示していることからこ の因子は敏捷性因子と解釈するのが妥当であろう ・また，この第 5 因子は表 4 の 4 と 5 欄から，レ ベル 4 において涾スピード，局の柔軟性と解釈さ れた能力領域から分化した能力領域が統合して形 成された能力領域であると推測される・

(6) 回転レベル 6 ;

これまでと同様な手順によって群化された表 4 の 6 㭷の 6 因子を解釈すると，第 6 因子以外の因 子は, レベル 5 においてとはぼ同様な変量に高い 負荷量を示していることから，第 1 因子から第 5 因子までは，レベル 5 の場合と同様に各々体前・ 後届及び体側届柔㳄因子, 泳スピード因子, 体捻

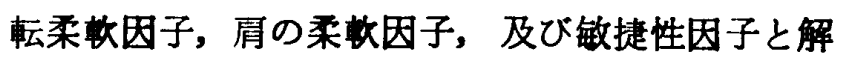
䣋されるであろ5.第 6 因子は足首伸展と可動性 にのみ最大の負荷量を示していることから，この 因子は足首伸展・可動柔㳄因子と解釈されるであ ろ5.また表 4 の 5 と 6 欄から，この第 6 因子は レベル 5 において泳スピード因子と解䣋された能 力領域から分化した能力領域であると推測され る.

（7）回転レベル 7 ；
表 4 の 7 橍の群化された 7 因子を解釈すると, 第 7 因子以外の因子はレベル 6に打いてとほぼ同 様な変量に高い負荷量を示していることから，第 1 から第 6 までの因子は，レベル 6 の場合と同様 に各々体前・後届及び体側屈柔軟因子，泳スピー ド因子,体捻転柔㪀因子，厉の柔剩因子，敏捷性因 子，及び足首伸展・可動柔軟因子と解釈してよい であろ5．第 7 因子は足首届曲にのみ最大の負荷 量を示していることから，この因子は足首届曲柔 杴因子と解釈されるであろう，さらにまた，表 4 の 6 と 7 欄から，この因子はレベル6において体 前・後届及び体側届柔饮性と解釈された能力領域 から分化して形成された能力領域と推測される.

(8) 回転レベル 8 ;

表 4 の 8 欄の群化された 8 因子を解釈すると， 第 2 ,第 3 及び第 4 因子は, 各々レベル 7 において とほぼ同様な変量に高い負荷量を示していること から，レベル 7 の場合と同様に各々泳スピード因 子，体捻転柔㜞因子，肩の柔軟因子と解釈される であろ5．第1因子は体側屈を，第8因子は体前 ・後屈をそれぞれ代表する変量に高い負荷量を示 していることから，第 1 及び第 8 の両因子は各々 体側屈柔軟因子, 体前 - 後庙柔㳄因子と解积され るであろ5.また表 4 の 7 と 8 闑からここで解釈 された上記の両因子は，レベル 7 において体前・ 後届及び体㑡屈柔㳄因子と解釈された能力領域か 分化して形成された能力領域であろうと推測さ れる.一方, 第 5 因子はバーピーテスト, 側方曲 げ，プル数等の体及び上肢運動のスピードあるい は敏捷性が関与した変量に，また第 7 因子はタッ ピング、ステッピング等の四肢運動の敏捷性が関 与した変量に高い目荷量を示していることから， 上記の両因子は各々体及び上肢運動の敏捷性因 子，四肢運動の敏捷性因子と解釈されるであろ 5.さらにまた, 表 4 の 7 と 8 欄からここで解釈 された両因子はレベル7において敏捷性因子と解 釈された能力領域が分化し，それに泳スピード能 力と解釈された能力領域から一部, 分化した能力 領域が統合して形成された能力領域であろ5 と推 測される。市，第 6 因子は，足首可動性・伸展 ・屈曲等の足首の柔㳄性に関与る变量に高、目荷 荲を示していることから，この因子は足首柔軟因 
子と解釈されるであろ5。さらに，表 4 の 7 と 8 欄から，この能力領域はレベル 7 において足首庙 曲柔秋性，足首伸展・可動柔敌性と解釈された能 力領域が統合して形成された能力領域であると推 測される・

（9）回枟レベル 9 ;

表 4 の 9 欄の群化された 9 因子を解釈すると， 第 6 と第 9 因子以外の因子はレベル 8 においてと 同様な变量に高い負荷量を示していることから， 第 1 ，第 2 ，第 3 ，第 4 ，第 5 ，第 7 及び第 8 因 子はレベル 8 の場合と同様に，各々体側屈柔覀因 子，泳スピード因子，体捻転柔㳄因子，局の柔㳄 因子，体及び上肢運動の敏捷性，四肢運動の敏捷 性因子, 及び体前 ・ 後届柔軟因子と解釈されるで あろ5. また第 6 因子は足首伸展・可動性に，第 9 因子は足首屈曲に高い負荷量を示していること から，両因子は各々足首伸展・可動柔㳄因子，足 首届曲柔饮因子と解釈されるであろ5. しかし， これらの因子は，表 4 の $7 ， 8$ 及び 9 欄からみて レベル8においていったん統合し，足首柔㳄性と 解釈された能力領域が再び分化して形成された能 力領域であると推測される。

(10) 回枟レレベル10;

これまでと同棣な手順によって群化された表 4 の10榴の 10 因子を解釈すると，第 5 因子及び第10 因子以外，いずれの因子むレベル9においてとは ほ同棣な変量に高い負荷量を示していることか 5 ，第 1 ，第 2 ，第 3 ，第 4 ，第 6 ，第 7 ，第 8 及び第 9 因子はレベル 9 の場合と 同粎に各々体侧 届柔饮因子，泳スピード因子，体捻枟柔吹因子， 肩の柔㳄因子，足首伸展・可勤柔㳄因子，四肢運 功の敏唗性因子，体前・後用柔欧因子，及び足首 届曲柔吹因子と解䣋されるであろ5，第 5 因子は 側方曲げとベンドフンドッイストに，また第 10 因 子はプル数とパーピーテストに高い負荷量を示し ていることから，両因子は各々躯幹及び上肢運動 の敏捷性因子，体及び上肢運動のスピード因子と 解釈されるであろ5。さらに，ここで解釈された 上肢運動のスピードはレペル 9 において体及び上 肢運動の敏捷性と解釈された能力領域が分化して 形成され，躲幹及び上肢運動の敏唗性は，分化し た他の能力領域にレベル 9 において肩の柔靯性と
解釈された能力領域から分化した能力領域が統合 して形成された能力領域であろらと推測される。

(11) 回転レベル11;

これまでと同様にして群化された表 4 の11眮の 11因子を解釈すると，第10因子と第 11 因子以外の 因子は各々レベル10Kおいてとほほ同様な変量に 高い負荷量を示していることから，第 1 因子から 第 9 因子まではレベル9の場合と同様に各々体側

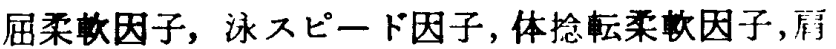
の柔㜞因子，稫幹及び上肢運動の敏捷性因子，足 首伸展・可動柔㜞因子，四肢運動の敏捷性因子， 体前・後屈柔敦因子，及び足首届曲柔軟因子と解 釈されるであろ5．第11因子はバーピーテストに のみ最大の因子負荷量を示していることから，こ の因子は体運動の敏捷性因子と解瀵されるである 5. 第10因子はプル数と股外転に高い負荷量を示 していることから，この因子は上肢運動のスピー ド及び開脚柔䡉因子と解釈されであろう。また， 表 4 の10と11欄から，上記の両能力領域はレベル 10に扎いて上肢運動のスピードと解釈された能力 領域が分化して形成された能力領域であろ5と推 測される。

(12) 回枟レベル12;

これまでと同様な手順によって群化された表 4 の12闢の12因子を解釈すると，第10因子及び第12 因子以外の各因子は各々レベル11においてはぼ同 様な変量に高い負荷量を示していることから，レ ベル11の揚合と同侎に各因子は番号の小さいもの から順番に各々体㑡届柔㪀因子，泳スピード因 子，体捻枟柔㳄因子，肩の柔欧因子，䡒幹及び上 肢運動の敏捷性因子，足首伸展 - 可動柔袣因子， 四肢軍理の敏提性因子，体前・後屈柔饮因子，足 首届曲柔欧因子，及び体運動の敏捷性因子と解釈 されるであろ5，一方，第10因子はプル数に高い 真荷量を示していることから，この因子は上肢運 動のスピード因子と解釈されるであろ5. 第 12因 子は股外伝と平泳に高い負荷量を示している．し かし，負荷量は前者の方が高く，平泳は脚による 推進力の方が腕による推進力より大な唯一の泳法 であり，しかも両脚を同時に後方に開いてキック するとい5特徽があることからここで平泳とい う変量によって定義される能力領域は泳スピード 


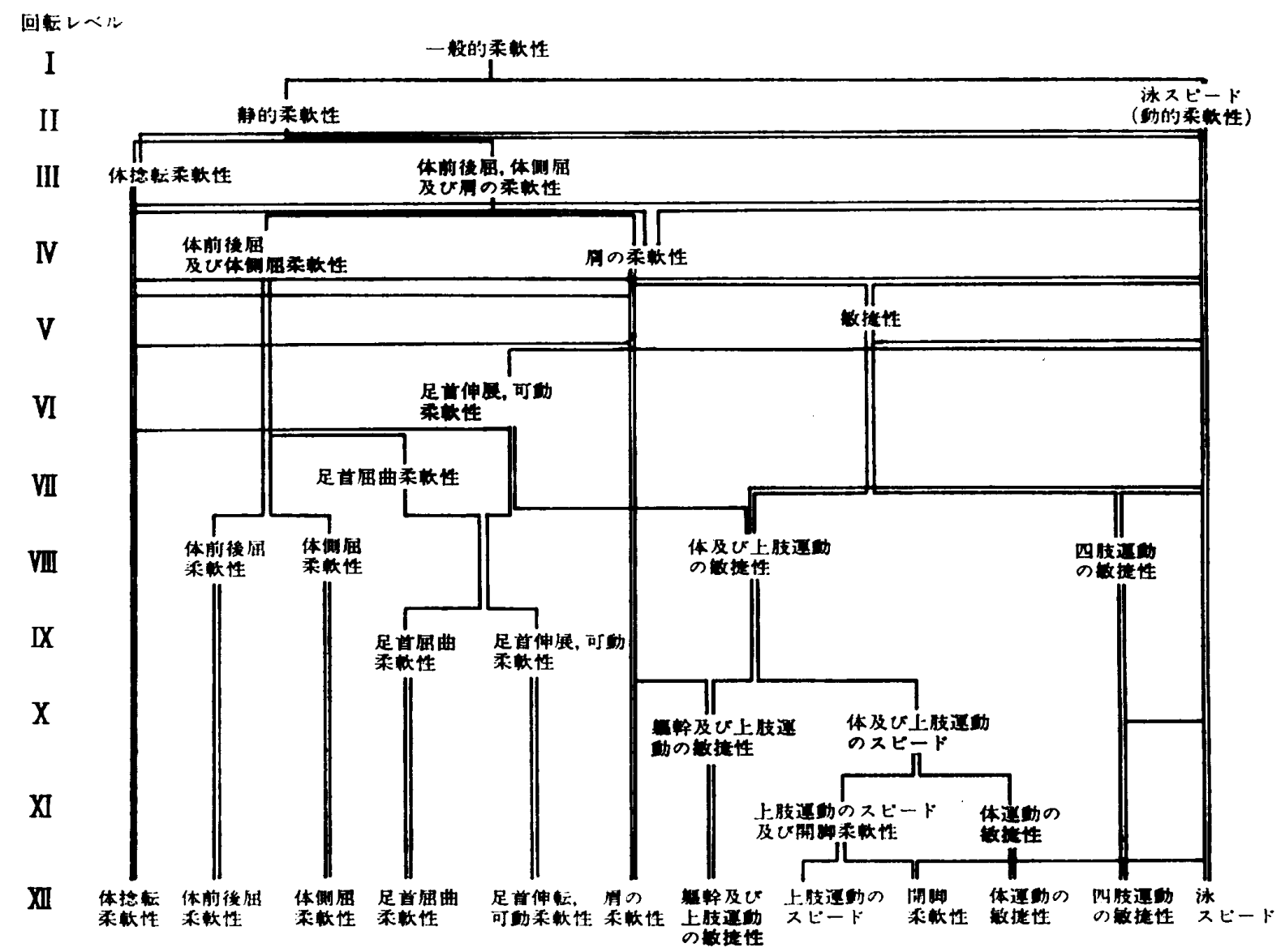

图 2 条㳄性の系統㴻

という能力領域よりもむしろ股外枟が定義する能 力領域と共通な能力領域を定義していると考えら れる・したがって，この因子は開脚柔䛢因子と解 釈してよいであろう．また，表 4 の11と12欗から ，ここで解釈された上腕運動のスピードと開脚柔 喍性の能力領域はレペル11において上腕運動の スピード及び開脚柔䖝性と解釈された能力領域が 分化して形成された能力領域であろうと推測され る。

以上，各回転レベルにおいて解釈された能力領 域を総合・整理し，系統四に描くと困2 通りになる.図 1 と図 2 の比較から，一般的柔㳄 性とい5 あのが存在し, それが静的巢鞂性と動的 柔䄳性（身体運動のスピード）の 2 能力領域に分 化与ると仮定したところまでは D.C. Nicks と E. A. Fleishman の仮説と今回の結果とは一致し ているが，それ以下のレベルでは異なった様相を している.すなわち，彼らが仮説したように些に 能力領域がいくつかの䋃純で具体的な小能力領域 に分化していくといらのではなく，複雓な分化・
統合の過程を経てょり単純で具体的な能力領城へ と分化していくものと推測されるまた，図から のみ見ると，体捻枟柔㳄性の能力領域はレベル 3 から12まで同様に解釈されている.しかし，因子 の複雑度はその因子を定義する変量数の大小によ って決定されるので, この観点から表 4 を見る と，この体捻枟柔欧性の能力頜域はレベル 3 では 8 変量によって定義され，レベル 4 では 5 変量に よって，レベル 5 と 6 では 4 変量によって,さら にレベル 7 以下では 3 変量によってと次第に少な い変量によって定義されている，したがって，レ ベ 3から12まで解积された能力名は同じであっ ても定義された能力領域そのすのは，レベルが進 むに従い, 上り解純で具体的な能力へと变化して いくものと推測される。

$$
\text { IV. ま と め }
$$

以上，階級的因子モデルの立場に立ち，D.C. Nicks と E.A. Fleishmanの仮説を作業仮説とし て選択した柔軟性のテスト項目を，柔軟性がその 
運動成就に重要な役割を果していると考えられる 大学男子水泳選手に実施した。 そして $30 \times 30$ の変 量からなる相関行列に，主因子解法を逼用し， 全分散の $85 \%$ 以上を説明する 12 因子を抽出し， ROTOHIST 法を適用して因子を一つずつ増や し, 順次 Normal Varimax 法にて直交回転を行 ない，抽出された因子を各回枟レベルで解釈及び 考察し，その結果を総合・整理して柔欧能力の系 統樹図を描き，柔敌能力の階級的因子構造を検討 した.

今回の結果と D.C. Nicks と E.A. Fleishman の仮説とは，一般的柔敵性が存在し，それが静的 柔故性と動的柔㳄性の能力領域に分化するところ までは一致するが，それ以下のレベルでは異なっ た構造をしていると推测された。すなわち，筆に 能力領域が分化して単純な能力領域に達するので はなく, 複雑な分化・統合の過程を経て, より具 体的で単純な能力へと分化していくものと推測さ れた。また，低次レベルで独立した能力領域（例 えば，体捻枟柔制）が形成され，澢次レベルま で（解釈された）能力名は同じであっても，その 能力自体はより単純で具体的な能力へと变化して いるものと推測された。

以上の推論は，階級的因子モデルの立場に立ち D.C. Nicks と E.A. Fleishman の仮説を作業仮 説として選択したテスト項目を，大学男子水泳選 手に対して実施し，得られた資料に因子解法技郝 としてROTOHIST法を適用した結果得られたも のである.したがって，本研究に打ける推論は上 記の標本, テスト項目, 分析法, 等々の限界内で 行なわれたものであるといらことを認識しておく ベきであろ5。

\section{文献}

1) Bester, G.L., "The Effects of an Isometric Weight Training Program on Speed in Three Competitive Strokes in College Swimming," Doctoral Dissertation, Univ. of Arkansas, 1972.

2 ) Burt, C., "Subdivided Factors," British J. of Psychology (Statistical Section), 2: 41-63, 1949.

3) Burt, C., "Alternative Methods of Factors Analysis," British J of Psychology (Statistical
Section), $2: 98-121,1949$.

4 ) Burt, C., "Group Factors Analysis," British J. of Psychology (Statistical Section), 3:4075, 1950.

5 ) Clarke, H.H., Application of Measurement to Health and Physical Education, 4th. Prentice-Hall. Inc., 1950. p. 202.

6) Collins, P.A., "A Film Analysis of Selected Swimming Strokes Kicks," Doctoral Dissertation, The Univ. of Iowa, 1968.

7 ) Counsilman, J.E., "Thery of the Flutter Kick," Beach and Poo, $6: 12,1949$.

8 ) Coumsilman, J.E., The Science of Swimming, Prentice Hall, Inc., 1968, pp. 204, and 308.

9) Coumsilman, J. E., Competitive Swimming Manual for Coaches and Swimmers, Counsilman Co. Inc., 1977, pp. 125-30.

10) Cureton, T.K., "Mechanics and Kinesiology of Swimming (the Crawl Flutter Kick)," Res. Quart., 1-4:87-121, 1930.

11) Cureton, T.K., "Flexibility as an Aspect of Physical Fitness," Res. Quart., 12-3:381 91, 1941.

12) Cureton, T.K., Physical Fitness Champion Athletes, Univ. of Illinois Press, 1951, pp. 11 -60 .

13) Dickson, C. A., "The Effects of Swimming Instructional Method on Sulected Aspects of Physical Fitnes," Doctoral Dissertation, Texas. Univ. 1971.

14) Healey, J., "A Competive Study to Determine the Relationship between Planter Flexion at the Ankle Joint and Saccess in Selected Skilled in Swimming," Doctoral Dissertation, Univ. of Utah, 1970.

15) Hillard, J.E., "The Effects of Vertical and Horizontal Kicking Practice in Intermediate Swimming on Water Propulsion and Selected Measures of Physical Performance," Doctoral Dissertation, Univ. of Utah, 1972.

16）井上フミ・松浦義行「発有に伴了運動能力甘好子構造 の変化次いて（遈動能力系統樹)」体育学研究, 21 一 1:21-37, 1976.

17）牛上フミ・松浦義行「Performance Test Kよって 測定される能力領钱の愉的」体骨学研究 $23-3: 215$ 
$-29,1978$.

18) Jorndt, G.T., "The Effects of Exercise on Ankle Flexibility and on Three Swimming Kicks," Doctoral Dissertation, Univ. of Utah, 1973, p. 1 .

19) Larson, L.A. and Yocom, R.D., Measurement and Evalution in Physical Education, Health, and Recreation, St. Louis, The C.V. Mosby. Co. 1951 .

20) Lawther, J.D., “Flexibility tor What," J. of Health, Physical Education and Recreatlon, 27, 23, 1956.

21) Lewin, G., Schwin Sport, Sportverlag Berlin, 1974. pp. 19 and 136.

22）松浦義行「筋力の階級的因子の测定」体育学研究 $11-4: 196-202,1967$.

23）松浦義行「筋力の階級的因子槽造」体青学研究
$12-1: 17-23,1967$.

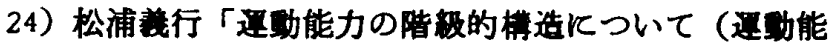
力系統㴻)」体育学研究 17-5:297-307，1973.

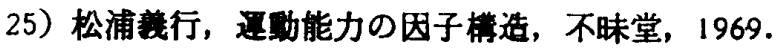

26）松田岩男・小野三周，スポーツマンの体力测定， 大垃馆， 1974 .

27) Nicks, D.C. and Fleishman, E.A., "Whatdoes Physical Fitness Test Measure? A Review of Factor Analytic Studies," Educational and Psychological Measuement," 22-1 : 77-95, 1962.

28）大山良德，体力づくりと身体柔軟性，不昧堂， 1974, pp. 224 56 .

29) Zavala, A., "Determining the Hierarchical Stracture of a Maltidimensional Body of Information," Perceptional and Motor Skills, 32 : 732 $-46,1971$. 